\title{
The Antimycobacterial Activity of B 663
}

\author{
VINGENT G. BARRY and MICHAEL L. GONALTY \\ Laboratories of the Medical Research Council of Ireland, \\ Trinity College, Dublin
}

B 663 is one of a large series of rimino-compounds of structure I synthesized originally in these laboratories as potential antimycobacterial agents. These are orange-red phenazine derivatives whose colour is related to their quinoneimine character. In $\mathrm{B} 663, \mathrm{R}^{\prime \prime}$ represents - $\mathrm{CH}\left(\mathrm{CH}_{3}\right)_{2}$ and $\mathrm{R}^{\prime}$ and $\mathrm{R}^{\prime \prime \prime}$ are $\cdot \mathrm{C}_{6} \mathrm{H}_{4} \mathrm{Cl}(p)$ residues. The synthesis and chemistry of these compounds have been described by Barry and co-workers in a series of papers (1956a, 1956b, I 956c, I 956d, I 958a, I 958b, I 959, I 962b).

The forerunner of these compounds, anilinoaposafranine $\left(\mathrm{I}, \mathrm{R}^{\prime \prime}=\mathrm{H}, \mathrm{R}^{\prime}=\mathrm{R}^{\prime \prime \prime}=\mathrm{Ph}\right)$, had been shown to be highly inhibitory of the growth of tubercle bacilli $\left(\mathrm{H}_{37} \mathrm{Rv}\right)$ in vitro (Barry et al I 948). It had also shown activity in mouse and guinea-pig tuberculosis (Barry I95 I; Conalty I 95I; Barry et al i956e) and in human renal disease (Lane I95I). Allday and Barnes (I952) used it with some success in leprosy patients in Nigeria.

I.

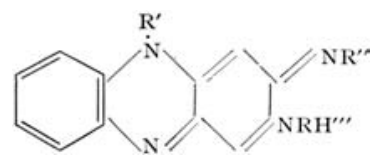

B 663 ( $1 . \mathrm{R}^{\prime \prime}=\mathrm{CH}\left(\mathrm{CH}_{3}\right)_{2}$ is a crystalline material insoluble in water but highly soluble in fat. Its inhibitory activity as determined by our methods (Conalty I 954) against $\mathrm{H}_{37} \mathrm{Rv}$ and a number of atypical mycobacteria is shown in Table I.

\section{Mice}

In murine tuberculosis B $66_{3}$ is extraordinarily active (Barry et al i 957). At the low dose of I $\mathrm{mg} . / \mathrm{kg}$. bodyweight in the diet for I4 days, beginning on the day of infection with the bovine Ravenel Rv strain, B 663 produces a significant extension of survival time. Again, mice which received I $\mathrm{mg}$. each of $\mathrm{B} 663$ intraperitoneally once only, on the I I th day of an infection which

\section{TABLE I \\ Antimycobacterial Activity of $B 663$}

in vitro*

\begin{tabular}{|c|c|}
\hline Mycobacterium & $\begin{array}{l}\text { Concentration causing } \\
\text { complete inhibition of } \\
\text { growth }(\mu \mathrm{g} . / \mathrm{ml} .)\end{array}$ \\
\hline $\begin{array}{l}\text { Myco. tuberculosis, } \mathrm{H}_{37} \mathrm{Rv} \text { includ- } \\
\text { ing wild, isoniazid-resistant, } \\
\text { streptomycin-resistant and PAS- } \\
\text { resistant strains }\end{array}$ & I. $3-3 \cdot 3$ \\
\hline $\begin{array}{l}\text { Myco. bovis, Ravenel Rv, wild } \\
\text { and drug-resistant strains. Also } \\
\text { BCG }\end{array}$ & I. $3-3 \cdot 3$ \\
\hline Myco. avium, three strains & $5.0-10.0$ \\
\hline $\begin{array}{l}\text { 'Unclassified' Mycobacteria } \\
\text { Myco. kansasii, two strains } \\
\text { Scolochromogens, two strains } \\
\text { Bättey types, Io strains } \\
\text { Runyon Group IV }\end{array}$ & $\begin{array}{l}3 \cdot 3-5 \cdot 0 \\
3 \cdot 3-5 \cdot 0 \\
1.0-6.6 \\
6.6-20.0\end{array}$ \\
\hline Myco. ulcerans** & 2.0 \\
\hline
\end{tabular}

*Proskauer and Beck medium enriched with human serum, 5 per cent. Incubation for 14 days.

$* *$ Incubated at $32^{\circ} \mathrm{C}$.

caused the death of untreated mice in I9 days, had a median survival time (MST) of 79 days. Perhaps its most striking property is its genuine prophylaxis against tuberculous infection. Thus mice which were fed at the level of ro $\mathrm{mg} . / \mathrm{kg}$. in the diet for 14 days and then taken off treatment, were afforded a considerable degree of protection when challenged with the usual lethal intravenous infection with Ravenel $\mathrm{Rv}$ four weeks later (Barry and Conalty I958). In established disease (treatment from the sixth day of infection) B 663 orally $(5 \mathrm{mg} . / \mathrm{kg}$.) for $\mathrm{I} 4$ days effectively reverses the disease process. Further confirmatory reports on the activity of B 663 in murine tuberculosis have been published from 
other laboratories (Hirsch I958; Vischer et al I 958; Noufflard and Berteaux r 955a and r 958b; Acharya et al i 959; Grumbach I960; Drabkina and Ginsburg ig62). The drug is also fully active against strains resistant to isoniazid, streptomycin. PAS or thiosemicarbazones.

\section{Syrian hamster}

Vischer et al (1958) showed that B 663 exerted good curative properties in experimental tuberculosis of the hamster and in this animal also, a striking prophylactic effect could be demonstrated.

\section{Guinea-pigs}

The therapeutic activity of the drug in guineapig tuberculosis was much less impressive. Thus although when administered at a dosage level of I $40 \mathrm{mg}$. $/ \mathrm{kg}$. for 79 days, treatment beginning on the 2 Ist day of infection, the disease index was reduced from 44 to 8.5 , the disease being confined to the site of infection and the adjoining lymph nodes (Barry et al i 957), at lower dosage levels the results were disappointing. B 663 at $20 \mathrm{mg}$./ $\mathrm{kg}$. in the diet from the $2 \mathrm{~s}$ st day of infection produced a $5^{\circ}$ per cent extension in MST and notably less lung disease in the treated animals. Vischer et al (1958), Steenken et al (1960) and Drabkina and Ginsberg ( 1962 ) also reported unimpressive results in this animal species.

\section{Rabbits}

In established disease experiments in rabbits, Freerksen observed a good therapeutic effect with oral doses of $50 \mathrm{mg} . / \mathrm{kg}$./day.

\section{Monkeys}

As with the guinea-pig, results of treatment in the monkey were also disappointing. Schmidt ( I 959) administered B 663 by stomach tube to infected monkeys. At Io mg./kg./day there was some effect and at Ioo mg./kg./day the effect was marked when treatment was initiated at the time of infection. When, however, treatment was withheld for 30 days after infection, the drug even at the larger dosage level failed completely to hold the disease. Bacilli recovered from the treated monkeys at autopsy were reported to have a reduced susceptibility to $\mathrm{B} 663$.

\section{In vitro resistance}

Under our conditions, growth of the human
$\mathrm{H}_{37} \mathrm{Rv}$ and the bovine Ravenel strains of $M y c o$. tuberculosis (0.03 mg. inocula) in Proskauer and Beck medium, to which 5 per cent human serum is added, is normally inhibited by $\mathrm{I} .3$ to 3.3 $\mu \mathrm{g} . / \mathrm{ml}$. B 663. To study the development of resistance to $\mathrm{B} 663$ the procedure adopted was to set up serial dilutions of the drug ( $\mathrm{I} \frac{1}{2}$ fold steps) and inoculate with $0.03 \mathrm{mg}$. of tubercle bacilli. After two to six weeks incubation, such growth, in the tubes of the highest concentration of drug, as was adequate in amount, was used as inocula for further series. The procedure was repeated at two to six weeks intervals. Under these conditions, I 5 successive subcultures produced no change in susceptibility although the total exposure to B 663 was 80 weeks. In other experiments employing io fold inocula of the Ravenel strain slight growth was evident at I oo $\mu \mathrm{g} . / \mathrm{ml}$. in the fourth serial culture and growth was as heavy as in the control tubes at this concentration of $\mathrm{B} 663$ after the $14^{\text {th }}$ subculture or a total exposure time of 7 I weeks. With the $\mathrm{H}_{37} \mathrm{Rv}$ strain under these same conditions the fifth serial culture showed some growth in the presence of $50 \mu \mathrm{g} . / \mathrm{ml}$.

The Ravenel strain which was now growing freely (large inoculum) at i oo $\mu \mathrm{g} . / \mathrm{ml}$. of B 663 also grew freely at this concentration when the usual small (o.03 mg.) inocula were employed. When given to mice in the standard intravenous inocula (o. I mg.) it proved to be still moderately virulent despite the long period of subculturing - all dead at 66 days with a MST of 28 days. A group of ro mice also infected in this way but treated for 14 days with $\mathrm{B} 663$ in the diet (20 mg./kg.) had a median survival time of I 20 days, only one mouse dying within 95 days. These cannot be considered resistant bacilli.

\section{In vivo resistance}

Mme Grumbach ( I 960) has isolated variants of $\mathrm{H}_{37} \mathrm{Rv}$ from mice treated for three and four months at a dosage level of I mg./mouse/day. These bacilli were much less susceptible to B 663 in vitro and it needed five to ten times the dose of drug to control infections produced by them in mice.

Schmidt also isolated bacilli of reduced susceptibility from monkeys treated with B 663 ( $100 \mathrm{mg} . / \mathrm{kg} . / \mathrm{day}$ ) for five months. One of these variants which we studied had a very low virulence in mice. It was reisolated after four 
months from mice which had been treated for I 4 days with B 663 (5 mg./kg.) and still showed reduced susceptibility in vitro. Inoculated again into mice it had now fully recovered its virulence but responded to treatment with B 663 (20 mg./ kg.). The same variant kept on subculture in Lowenstein slopes for 18 months fully recovered its susceptibility to B 663 in vitro, its virulence for mice and also its susceptibility in the mouse to treatment with B 663 .

An observation of great interest which we have made and which has been confirmed by Grumbach (I96I) is that tubercle bacilli which have emerged from in vitro studies or in the mouse and monkey and which exhibit a reduced susceptibility to $\mathrm{B} 663$ are still susceptible to other rimino-compounds, e.g. B $749\left(\mathrm{I}, \mathrm{R}^{\prime}=\mathrm{R}^{\prime \prime \prime}\right.$ $=$ parachlorophenyl; $\left.\mathrm{R}^{\prime \prime}=\mathrm{N} \cdot \mathrm{CH}_{2} \cdot \mathrm{CH}_{2} \mathrm{NEt}_{2}\right)$. This phenomenon is being studied further.

Bacilli resistant to isoniazid or ethionamide can be developed readily in a few subcultures in a tween-free medium enriched by serum. We have shown that if sub-inhibitory concentrations (e.g. $0.5 \mu \mathrm{g} . / \mathrm{ml}$.) of B 663 are present, no change in susceptibility of $\mathrm{H}_{37} \mathrm{Rv}$ to isoniazid could be demonstrated after ten successive titrations extending over a period of 17 months. In a series of experiments in mice infected with the $\mathrm{H}_{37} \mathrm{Rv}$ strain of Myco. tuberculosis, Grumbach (I960) has shown that, under treatment with B 663 ( 6 to $20 \mathrm{mg} . / \mathrm{kg}$.) or isoniazid (4 to $5 \mathrm{mg} . / \mathrm{kg}$.) or ethionamide ( 40 to $50 \mathrm{mg} . / \mathrm{kg}$.), the bacillary count in the lungs falls rapidly until about the $65^{\text {th }}$ day and then in each case begins to rise rapidly again. This is the well-known 'fall and rise' phenomenon associated with the development of drug-resistant bacilli. When, however, B 663 was combined with isoniazid or ethionamide, at the dosage levels mentioned, the bacillary count continued to fall, reaching almost zero in I 50 days, and no resistant bacilli appeared. Vischer and Roulet ( 1963) also found that B 663 delayed the emergence of isoniazid resistant strains in mice.

\section{Absorption, distribution and retention}

The genuine chemoprophylaxis of B 663 against experimental tuberculosis referred to earlier makes the pharmacology of this substance of great interest (Barry et al 1959b, i 960). As ordinarily presented in powder form, B 663 on ingestion is absorbed in amounts adequate to exert high antituberculosis activity in the mouse, hamster and rabbit. It is also well absorbed in the rat. Blood levels attainable in the guineapig are very low and in man 9o per cent of the drug presented in this state is excreted unchanged in the faeces. To counter this poor absorption in man the drug has been prepared in micronized form by Dr E. Hodel, Geigy Pharma, Basle.

In mice B 663, whether given as a powder or in micronized form, is well absorbed. At the end of 28 days treatment with B 663 (25 mg./kg.) in the diet, the lungs contained approximately $800 \mu \mathrm{g} . / \mathrm{g}$., the spleen 4 , $000 \mu \mathrm{g} . / \mathrm{g}$., the fat $800 \mu \mathrm{g} . / \mathrm{g}$. and the plasma $3.0 \mu \mathrm{g} . / \mathrm{ml}$. Twentyone days off treatment reduced these values to 60 (lungs), 85 (spleen), $35^{\circ}$ (fat) and I.I (plasma). Higher dosage or extended periods of treatment had little effect on the plasma level.

In rats treated at the high level of Ioo mg./ kg./day in the diet, plasma levels reached $8 \mu \mathrm{g} . / \mathrm{ml}$. and lung levels, I, ooo $\mu \mathrm{g} . / \mathrm{g}$.

Guinea-pigs on a dose of $20 \mathrm{mg}$. $/ \mathrm{kg}$. continued for 30 days proved to have $140 \mu \mathrm{g}$. $/ \mathrm{g}$. of drug in the lungs but even at the end of this period plasma levels never reached even I $\mu \mathrm{g} . / \mathrm{ml}$. At the end of 326 days treatment $(50 \mathrm{mg} . / \mathrm{kg}$. in the diet) the plasma level was still little more than I $\mu \mathrm{g} . / \mathrm{ml}$. although the lung tissue contained I $8,500 \mu \mathrm{g} . / \mathrm{g}$.

In man when the drug is given orally in the micronized form 70 to 90 per cent is absorbed and serum levels on a dosage of $600 \mathrm{mg}$. per day reach 3 to $4 \mu \mathrm{g} . / \mathrm{ml}$.; skin and lymph node may contain $40 \mu \mathrm{g} . / \mathrm{g}$. (Knight r 964). Excretion is slow and some colour may be seen in the urine many weeks after cessation of treatment.

\section{Reticulo-endothelial system}

The low plasma and high tissue levels of B 663 which can be reached in different animal species are due to the active take up of the drug by the cells of the reticulo-endothelial system (Conalty and Jackson i 962a, I 962b). This phenomenon has so far been most studied in mice. When mice are treated at the rate of $50 \mathrm{mg} . / \mathrm{kg}$. (in the diet), in three to four days orange-red rounded bodies, I to $2 \mu$ diameter, appear in the cytoplasm of macrophages. On continuing treatment bright red crystals are seen accompanying the round inclusions (seven 
to ten days) and at the end of a few weeks most of the cells contain crystals only. The above sequence of events is particularly well seen in the mesenteric lymph nodes and in the spleen. The appearance of crystals in the lung macrophages is somewhat delayed. Macrophages already loaded with crystals continue to take up carbon particles and tubercle bacilli. B 749, the analogue of B 663 referred to earlier, does not colour the fat in mice and appears even on prolonged treatment as a diffuse colouring of the cytoplasm and is never seen in crystalline form.

Apart from fat cells, B 663 is only noticeable in macrophages; its retention for long periods in these cells probably favours its therapeutic effect but its rapid withdrawal from the blood makes it difficult to establish or maintain therapeutic levels in some animal species. We had thought for this reason that another rimino-compound more soluble in aqueous media, e.g. B 749 also highly effective in mice, might produce higher blood-levels and thus show a better effect in, for example, the guinea-pig. Unexpectedly, however, we found that although B 749 does not accumulate to any extent in fat, it builds up very quickly in the solid tissues. So effective is the uptake of this drug by the macrophages that it has not been possible to obtain blood levels even as high as those obtained with B 663 treatment. Accordingly it is much less active than B 663 in guinea-pig tuberculosis.

The distribution of B 663 in the animal after ingestion, resulting in high concentrations in certain organs and low levels in the blood, throws some light on its therapeutic effect in different animal species. Thus it is very effective in the mouse and hamster where the bacilli tend to be intracellular and poor in the guinea-pig where the bacilli are for the most part extracellular. This is not the whole story, however; we know that B 663 is present at a very low level in the plasma in mice when an impressive prophylaxis can be demonstrated. It has been suggested that the binding and transport of the drug by serum proteins may be different in the mouse and guinea-pig. Binding to lipoprotein in the serum of mice is, however, complete and yet the therapeutic effect of the drug is excellent in this animal (Buggle). The nature of the lesions in experimental tuberculosis in different species is obviously of great importance.

\section{Murine leprosy}

In view of the intracellular location of B 663 in macrophages its examination in leprosy was clearly indicated. Chang ( I 962) states that 'B 663 has emerged as the most active drug yet tested in the treatment of murine leprosy'. It is the first drug to hold the infection in check for 8 I 6 days although the infection was not eradicated. Of various combinations of several antituberculosis drugs, the combination of B 663 and isoniazid was apparently the only one which caused an actual reduction of the established infection. There was evidence that in mice treated with this combination, Myco. lepraemurium acquires some degree of resistance to isoniazid but not to B 663. Shepard ( 1 963), emplying his mouse footpad technique, has shown that o. I per cent B 663 in the diet causes complete suppression of growth of human leprosy bacilli.

\section{Experience in man}

The first trial of B 663 in human leprosy was carried out by Browne and Hogerzeil (i 962a, I 962 b, I962c) who reported that B 663 had a definite action in lepromatous leprosy, inducing clinical and bacteriological improvement. No signs of toxicity were noticed over a 12 month period. A preliminary small scale trial has also been completed in Kuala Lumpur with encouraging results (Rees I964). Knight and his associates at the National Institutes of Health, Bethesda are conducting a very thorough examination of the behaviour of $\mathrm{B} 663$ in a small number of leprosy patients (Knight I964). Much more extensive clinical investigation of B 663 in leprosy has now been planned or is already under way in Nigeria, Malaya and elsewhere (Rees i 964) and when the resulting reports appear it will be possible to assess more completely the status of B 663 as an antileprosy drug.

\section{Other mycobacterial infections}

The report (Lunn and Rees i 964) of the successful treatment of mycobacterial skin ulcers, due to atypical mycobacteria resembling Myco. ulcerans, in Uganda with B 663 has aroused considerable interest. These authors also reported that B 663 showed a very high activity against three strains of Uganda mycobacteria, three strains of Myco. ulcerans and two freshly isolated strains from Australia. Standardized infections 
in the foot-pads of mice produced by these strains of mycobacteria were completely suppressed by 0.006 per cent of B 663 in the diet. This report has already led others to consider the possibility of exploiting B 663 in a variety of mycobacterial infections in man.

\section{A GKNOWLEDGEMENTS}

Grateful acknowledgement is made to Miss Joan Byrne for the in vitro determinations, Dr W. Steenken, Jun., Dr R. J. W. Rees, Dr A. T. Wallace, Dr J. A. McFadzean and Dr J. Marks for various strains of mycobacteria. This work is currently supported by the Rehabilitation Institution (Ireland).

\section{References}

ACHARYA, B. K., RobSOn, J. M. and sullivan, F. M. (I959). Amer. Rev. Tuberc., 80, $87 \mathrm{I}$.

allday, E. J. and barnes, J. (1952). Irish 7. med. Sci., 421. BARry, v. C. (I95I). Irish 7. med. Sci., 453.

BARRY, v. C. (1958). Bull. Un. int. Tuberc., 28, 200.

BARRY, v. C. (1964). The Chemotherapy of Tuberculosis, p. 46, ed. Barry, V. C. London: Butterworth.

BARRY, v. C., BELTON, J. G., CONALTY, M. L. and TWOMEY, D. (1948). Nature, 162, 622.

BARRY, v. C., BELTON, J. G., O'SUllivan, J. F. and TWOMEY, D. (1956a). 7. Chem. Soc., 888.

BARRY, v. C., BELTON, J. G., O'SULLIVAN, J. F. and TWOMEY, D. (1956b). 7. Chem. Soc., 893.

BARRY, v. C., BELTON, J. G., O'SUllivan, J. F. and TWOMEY, D. (1956c). 7. Chem. Soc., 896.

BARRY, v. G., BELTON, J. G., O'SUllivan, J. F. and TWOMEY, D. (I 956d). 7. Chem. Soc., 3347.

BARRY, v. C., CONAlTy, M. L. and GafFney, E. E. (1956e). 7. Pharm. Pharmacol., 8, io89.

BARRY, v. C., BELTON, J. G., CONALTy, M. L., DENNENy, J. M., EDWARD, D. W., O'SULLIVAN, J. F., TWOMEY, D. and WINDER, F. (I 957). Nature, I79, I O I3.

BARRY, v. G., BELTON, J. G., O'SUllivan, J. F. and TWOMEY, D. (1958a). 7. Chem. Soc., 859.

BARRY, v. G., BELTON, J. G., O'SUllivan, J. F. and TWOMEy, D. (1958b). 7. Chem. Soc., 907.

BARRY, v. G., BELTON, J. G., O'SULlivan, J. F. and TWOMEY, D. (1959a). 7. Chem. Soc., 32 I 7.

BARRY, v. C., BUGGLe, K., BYRNe, J., CONALTY, M. L. and Winder, F. (1959b). Bull. Un. int. Tuberc., 29, $5^{82}$.

BARRY, v. C., BUGGLE, K., BYRNE, J., CONALTY, M. L. and
WINDER, F. (1960). Irish 7. med. Sci., 345.

BARRY, v. C., Belton, J. G.; O'CALlaghan, C. N. and twomey, D. (1962a). Proc. Roy. Irish Acad., 62B, i 75.

BARRY, v. C., Belton, J. G. and TWOMEy, D. (1962b). Chemistry of Natural and Synthetic Colouring Matters and Related Fields, p. 589, ed. Gore, T. S. et al. London: Academic Press.

Barry, v. c. and conalty, m. L. (1958). Amer. Rev. Tuberc., 78,62 .

Browne, s. G. and hogerzeil, L. m. (i 962a). Leprosy Rev., 33, 6 .

BRowne, s. G. and hogerzeil, L. м. (1 962b). Leprosy Rev., 33, I 82 .

BROWNe, s. G. and hogerzeil, L. M. (I 962c). Leprosy Rev., 33, I 85 .

BUGGLE, $\mathrm{K}$. Unpublished work from these laboratories. CHANG, Y. T. (1 959). Leprosy Briefs, ro, 37.

Chang, y. т. (1962). Antimicrobial Agents and Chemotherapy, i 962, p. 294, ed. Sylvester, J. C., Ann Arbor, American Society for Microbiology.

CONAlty, M. L. (I 95I). Tubercle, 32, 263.

CONAlty, m. L. (1 954). Irish 7. med. Sci., 475.

CONAlTy, м. L. (1964). The Chemotherapy of Tuberculosis, p. I 5o, ed. Barry, V. C. London: Butterworth.

conalty, m. L. and Jackson, R. D. (i 962a). Ann. Histochim., Supp. 7, 22 I.

CONAlty, m. L. and Jackson, R. D. (1962b). Brit. 7. exp. Path., 43, 650.

Drabkina, R. O. and ginsberg, T. s. (ig62). Rozhl. Tuberk, 22, 325 .

FREER KSEN, E. Personal communication.

GRUMBACH, F. Personal communication.

grumbach, F. (1 960). Ann. Inst. Pasteur, 99, 567.

IIRSCH, J. (1958). TuberkArzt, 12, i 96.

KNIGHT, v. Personal communication.

LANE, T. J. D. (195I). Irish 7. med. Sci., 393.

LUNN, H. F. and REES, R. J. W. (I 964). Lancet, r, 247.

noufflard, H. and berteaux, s. (1958). Ann. Inst. Pasteur,

95, 449.

NOufflard, h. and berteaux, s. (ig6i). Path. Biol., 9, I037.

REES, R. J. W. (I 964). Personal communication.

schmidt, L. H. (i960). Bull. Un. int. Tuberc., 30, 3 I 6.

ShePARD, c. C. (1963). The Pathogenesis of Leprosy, p. 8o, ed. Wolstenholme, G. E. W. and O'Connor, M. London: Churchill.

steeknen, w., montalbine, v. and smith, m. м. (i 960 ). Amer. Rev. Resp. Dis., 81, 764 .

Vischer, w. A. and roulet, F. C. (I963). Beitr. klin. Tuberk., I26, 253.

vischer, w. A., TirunArayAnen, N. O. and Bruhin, M. (1958). Beitr. klin. Tuberk., 119, 59. 